\title{
Fungal Biotreatment of Agro-Industrial Wastes for the Production of Bioethanol in Bioreactor
}

\author{
T.S. El-Tayeb ${ }^{\#}$, A.A. Abdelhafez, S.H. Ali" and E.M. Ramadan ** \\ Department of Agricultural Microbiology; "Department of \\ Agricultural Chemistry, Faculty of Agriculture, Ain Shams \\ University, Shoubra El-Kheima and ${ }^{* *}$ Biotechnology \\ Laboratory, Heliopolis University, Cairo-Belbies Road, Cairo, \\ Egypt.
}

\begin{abstract}
R IOETHANOL production from lignocellulosic feedstocks is considered a promising strategy to increase global production of biofuels without impacting food supplies. This work aimed to evaluate bioethanol production by baker's yeast using a medium containing the hydrolysate of fungal biotreatment of five different lignocellulosic feedstocks with some amendments. The pretreatment of lignocellulosic feedstocks using $5 \% \mathrm{w} / \mathrm{v} \mathrm{NaOH}, 1 \% \mathrm{v} / \mathrm{v}_{2} \mathrm{SO}_{4}$ and sodium hypochlorite: $\mathrm{H}_{2} \mathrm{O}_{2}(10: 1)$ prior to fungal biotreatment was studied. For bioethanol production, batch, fed-batch (two strategies) and continuous cultivations of baker's yeast on the fungal biotreated rice straw hydrolysate was evaluated in bioreactor. In batch and pulsed fed-batch cultivations, the highest bioethanol concentration, conversion coefficient, bioethanol yield and productivity were $(0.41 \%$ $\mathrm{v} / \mathrm{v}, 36.9 \% \mathrm{v} / \mathrm{w}, 36.9 \% \mathrm{v} / \mathrm{w}$ and $0.114 \mathrm{ml} / \mathrm{l} / \mathrm{h}$, respectively), while in fed-batch cultivation with continuous feeding these parameters were $(0.45 \% \mathrm{v} / \mathrm{v}, 40 \% \mathrm{v} / \mathrm{w}, 40.5 \mathrm{v} / \mathrm{w} \%$ and $0.015 \mathrm{ml} / \mathrm{l} / \mathrm{h}$, respectively). The highest bioethanol concentration $(0.52 \% \mathrm{v} / \mathrm{v})$ was obtained in continuous culture at dilution rate of $0.03 \mathrm{~h}^{-1}$, while conversion coefficient, yield and productivity were $31.2 \% \mathrm{v} / \mathrm{w}, 31.4 \% \mathrm{v} / \mathrm{w}$ and $0.022 \mathrm{ml} / \mathrm{l} / \mathrm{h}$, respectively.
\end{abstract}

Keywords: Bioethanol, Agro-industrial wastes, Biotreatment, Baker's yeast, Trichoderma viride EMCC 107.

Lignocellulosic complex is the most abundant biopolymer on Earth. Many lignocellulosic feedstocks have been tested for bioethanol production. Processing of lignocellulosics is an essential step in releasing fermentable carbohydrate components for the production of bioethanol. This goal can be accomplished by combining pretreatment and hydrolysis steps that involve physical, chemical, thermal and/or enzymatic treatments. The main effect of pretreatment of lignocellulosic biomass is delignification by breaking the ester bonds crosslinking lignin and xylan, thus increasing the porosity of biomass. Several research approaches are being carried out to increase bioethanol yields from

\#Corresponding author mailing address: Department of Agricultural Microbiology, Faculty of Agriculture, Ain Shams University, Shoubra El-Kheima, 11241, Cairo, Egypt. E-mail: tarekeltayeb@yahoo.com. 
available feedstocks. In this respect, the alkali treatment of rice straw with $\mathrm{NaOH}$, peracetic acid (PA), and sodium chlorite $\left(\mathrm{NaClO}_{2}\right)$ resulted in a remarkable decrease in hemicellulose as well as lignin. The treated straw was biotreated with the culture filtrate of Trichoderma reesei. The degree of enzymatic hydrolyzation relative to the amount of residual straw was $69 \%$ (treated with $0.2 \mathrm{~N} \mathrm{NaOH}$ ), $42 \%$ (treated with $20 \% \mathrm{PA}$ ), and $50 \%$ (treated with $\mathrm{NaClO}_{2}$ ) (Taniguchi et al., 2005). Jakobsson (2005) pretreated wheat straw with steam at different temperatures $\left(190,200,210^{\circ} \mathrm{C}\right)$ and residence times $(2,5,10$ min) to make cellulose more accessible to enzymes. The straw was impregnated with sulphuric acid before pretreatment. The pretreatment at $190^{\circ} \mathrm{C}$ for $10 \mathrm{~min}$ resulted in the best overall yield of fermentable sugars. In another study, rice straw was pretreated using a solution containing $20 \mathrm{ml}$ sodium hypochlorite and $100 \mathrm{ml}$ hydrogen peroxide for $1 \mathrm{~g}$ rice straw resulted in $47.3 \mathrm{mg}$ glucose and $72.5 \mathrm{mg}$ xylose. The latter treatment was an essential step for efficient bioethanol production with Saccharomyces cerevisiae and Pichia stipitis. With initial $5 \%$ sugars concentration, the final ethanol concentration was about $1.67 \%$ (Choi et al., 2009). Silva et al. (2013) pretreated rice straw in alkaline medium (pH 8) in the presence of $\mathrm{H}_{2} \mathrm{O}_{2}$, increasing yeast fermentability of rice straw hydrolysate to double the bioethanol volumetric productivity in relation to the untreated hydrolysate.

Fungal biotreatment of lignocellulosic feedstocks for the obtainment of fermentable sugars for bioethanol production was investigated by many authors; Zhang et al. (2007) observed a maximum saccharification yield of $37 \%(\mathrm{w} / \mathrm{w})$ from biotreated bamboo residues with Coriolus versicolor. Biotreatment of wheat straw for $60 \mathrm{~d}$ with $P$. ostreatus resulted in $33 \%$ conversion of cellulose to glucose (Taniguchi et al., 1982). Manjunath \& Geeta (2007) biotreated sugarcane bagasse, paddy straw and wheat straw with the fungi Phanerochaete chrysosporium and Pleurotus spp. The filtrate fermentation of these materials showed maximum production of bioethanol on baggase $(0.08 \% \mathrm{w} / \mathrm{w})$ by Zymomonas mobilis. Wan \& Li (2010) was able to convert $57.7 \%$ of corn stover to glucose after biotreatment with the fungus Ceriporiopsis subvermispora for 18 d at $28^{\circ} \mathrm{C}$ and the highest overall bioethanol yield was $57.80 \%$. In another investigation, bioethanol was produced from hydrolysates of grass, hemp stem, wheat straw, newspaper, and cellulose resulted from pretreatment with acid or alkali and the enzymes Celluclast and Novozymes 188. Chemical pretreatment increased bioethanol yields from $0.8 \mathrm{mM} / \mathrm{g}$ to $3.3 \mathrm{mM} / \mathrm{g}$ from alkali-pretreated straw (Jessen \& Orlygsson, 2012).

Fermentation process development has great impact on efficient bioethanol production (Bai et al., 2004 and Laopaiboon et al., 2007). Typically, bioethanol production is often conducted in batch mode. However, the batch process has many disadvantages, particularly when the microorganisms are either slow growing or strongly affected by product inhibition. A report studied batch bioethanol production by Sacch. cerevisiae in bioreactor from raw sugar beet juice and the bioethanol yield was $59.89 \mathrm{~g} / \mathrm{l}$ and production efficiency $78.8 \%$,

Egypt. J.Microbiol. 49 (2014) 
and in fed-batch process the yield was $92.78 \mathrm{~g} / \mathrm{l}$ and efficiency $93.4 \%$. At the same time, batch bioethanol production from raw sugar beet cossettes resulted in the highest bioethanol yield of $54.53 \mathrm{~g} / \mathrm{l}$ and production efficiency of $79.5 \%$ (Pavlečić et al., 2010).

Control of the flow rate of medium feed is quite advantageous because the inhibitory effect caused by high substrate or product concentrations in the fermentation broth can be minimized. Souza et al. (2007a) proposed a pulse fedbatch strategy for bioethanol production and observed greater bioethanol productivity and lesser biomass formation during fermentation. Souza et al. (2007b) improved bioethanol production in a pulse fed-batch cultures. They resolved the lethal effect of bioethanol on cell survival by reducing the sucrose concentration in the fermentation system. Continuous processes permit many advantages including the decrease of product inhibition effect. Purwadi et al. (2007) employed a continuous cultivation system using a strain of Sacch. cerevisiae to ferment a non-detoxified spruce hydrolysate. At dilution rate up to $0.52 \mathrm{~h}^{-1}$, a bioethanol yield of $0.42-0.46 \mathrm{~g} / \mathrm{g}$ consumed sugars was achieved, and the residual sugar concentration was less than $6 \%$ of the initial fermentable sugars. Saha \& Cotta (2005) investigated the continuous production of bioethanol from alkaline peroxide pretreated and enzymatically saccharified wheat straw under various conditions. The average bioethanol produced from the available sugars $(21.9-47.8 \mathrm{~g} / \mathrm{l})$ ranged from 8.8 to $17.3 \mathrm{~g} / \mathrm{l}(0.28-0.45 \mathrm{~g} / \mathrm{g}$ available sugars, $0.31-0.48 \mathrm{~g} / \mathrm{g}$ sugar consumed) with bioethanol productivity of $0.27-0.78 \mathrm{~g} / \mathrm{l} / \mathrm{h}$ in a set of 14 continuous culture runs (16-105 days).

The aim of this work is to evaluate pretreatment and fungal biotreatment of some agro-industrial wastes in either shake flasks or bioreactor in order to improve the efficiency of bioethanol fermentation by different strategies. Bioethanol production in bioreactor was carried out, using baker's yeast, in batch, fed-batch and continuous cultivation techniques.

\section{Materials and Methods}

\section{Agro-industrial wastes}

Rice straw and corn stalks were collected from farms of rice and corn in ElBeheira Governorate (located in Lower Egypt in the Delta of the Nile north of Cairo. Sugar beet waste and sugarcane bagasse were obtained from the Sugars Refinery Factory at El-Beheira Governorate and sugarcane fresh syrup shops in Cairo, respectively. Sawdust was gathered from the local joinery atelier at Heliopolis University, Cairo, Egypt. Corn stalks were coarsely crushed using a laboratory hammer mill (Retsch GmbH \& Co. KG, Germany). The other agroindustrial wastes were chopped into small pieces using a shredder and then ground to pass through $1.5 \mathrm{~mm}$ screens. All samples were homogenized and oven-dried at $45^{\circ} \mathrm{C}$. The dried materials were stored in air tight containers at room temperature before use. 


\section{Microorganisms}

Cellulose degrading fungi: Trichoderma viride EMCC 107 were obtained from Cairo Microbiological Resources Center (Cairo MIRCEN), Faculty of Agriculture, Ain Shams University, Cairo, Egypt. Bioethanol producing organism: Fresh commercial baker's yeast was purchased from a local bread bakery in Cairo.

\section{Pretreatment of agro-industrial wastes before fungal biotreatment}

Five grams of each residue (rice straw, corn stalks, sawdust, sugar beet waste or sugarcane bagasse) was placed in $250 \mathrm{ml}$ conical flasks. Each flask contained $100 \mathrm{ml}$ of either of the following solutions: $5 \% \mathrm{w} / \mathrm{v} \mathrm{NaOH}, 1 \% \mathrm{v} / \mathrm{v} \mathrm{H}_{2} \mathrm{SO}_{4}$ and sodium hypochlorite: $\mathrm{H}_{2} \mathrm{O}_{2}(10: 1)$. Treatments with $5 \%$ w/v NaOH, $1 \% \mathrm{v} / \mathrm{v}$ $\mathrm{H}_{2} \mathrm{SO}_{4}$ were incubated for $2 \mathrm{~h}$, while the treatment with sodium hypochlorite: $\mathrm{H}_{2} \mathrm{O}_{2}$ (10:1) was incubated for $24 \mathrm{~h}$. The flasks were placed on a shaker at $30^{\circ} \mathrm{C}$ with gentle mixing $(120 \mathrm{rpm})$ for $1 \mathrm{~h}$. After treatment, all residues were washed carefully with tap water and rinsed adequately and the final $\mathrm{pH}$ was adjusted to 7.0 before using in biotreatment experiments. The most efficient pretreatment process was conducted on sufficient amount of rice straw needed for biotreatment in bioreactor.

\section{Biotreatment of agro-industrial wastes}

T. viride EMCC 107 was grown and maintained on potato dextrose agar (PDA) slants. Fungal cultures were inoculated onto PDA medium in Petri plates. After 4-5 days of incubation at $28^{\circ} \mathrm{C}$, cultures were used for inoculation of medium containing different pretreated agro-industrial wastes. The fungal biotreatment of agro-industrial wastes in shake flasks prior to bioethanol production was carried out in submerged culture according to the method described in El-Tayeb et al. (2012). Shake flasks tests were performed in triplicates. For fungal biotreatment of rice straw in bioreactor, a 10 liter dished bottom bioreactor MS-1 (Major Science Instruments) was used. The vessel of bioreactor was equipped with lipseal stirrer assembly, automatic $\mathrm{pH}$ controller, automatic dissolved $\mathrm{O}_{2}$ and automatic temperature controller. Bioreactor containing $5 \% \mathrm{w} / \mathrm{v}$ pretreated rice straw was filled with medium described by El-Tayeb et al. (2012) and sterilized at $121^{\circ} \mathrm{C}$ for $25 \mathrm{~min}$. After inoculation, the final working volume was adjusted to 7 liters. For inoculum preparation, five discs (5 mm diam.) of the plate cultures of $T$. viride EMCC 107 were inoculated into $700 \mathrm{ml}$ of $2.0 \%(\mathrm{w} / \mathrm{v})$ malt extract medium in $1000 \mathrm{ml}$ conical flasks and incubated in shaker incubator at $28^{\circ} \mathrm{C}$ and $150 \mathrm{rpm}$ for $5 \mathrm{~d}$. The liquid inoculum was introduced aseptically into bioreactor. Fungal growth and rice straw degradation were monitored during $15 \mathrm{~d}$. The temperature and $\mathrm{pH}$ were kept constant at $28^{\circ} \mathrm{C}$ and 7.0 , respectively, with aeration at $1 \mathrm{vvm}$ and agitation at $200 \mathrm{rpm}$. After biotreatment, the residual materials were separated by filtration through filter cloth then through Whatman filter paper No.1. The filtrates were used for total fermentable sugars determination (AOAC, 2007) and bioethanol production. 
Bioethanol production from biotreated agro-industrial wastes

Bioethanol production was conducted in $250 \mathrm{ml}$ conical flasks containing $100 \mathrm{ml}$ of filtered hydrolysate resulting from the fungal biotreatment of different lignocellulosic feedstocks as basal medium. Flasks were amended with the following components $(\mathrm{g} / 100 \mathrm{ml})$ : yeast extract 1 , $\left(\mathrm{NH}_{4}\right)_{2} \mathrm{SO}_{4} 0.1, \mathrm{KH}_{2} \mathrm{PO}_{4} 0.1$, $\mathrm{MgCl}_{2}$ 0.1, and $\mathrm{pH}$ was adjusted to 5.0 (El-Tayeb et al., 2012). Baker's yeast was inoculated at $2 \% \mathrm{w} / \mathrm{v}$ in either flasks or bioreactor cultivations. Flasks were incubated in an anaerobic incubator (Hirayama Manufacturing Corp., Tokyo, Japan) at $30^{\circ} \mathrm{C}$ for $4 \mathrm{~d}$. The overall bioethanol concentration was determined colormetrically according to the method of Lau \& Luk (1994).

\section{Effect of medium composition on bioethanol formation}

For the optimization of bioethanol production medium, $250 \mathrm{ml}$ conical flasks containing $100 \mathrm{ml}$ of filtered hydrolysate derived from the fungal biotreatment of rice straw were used as basal medium. To the basal medium, six different amendments were added to flasks (including control) according to the following formulas: (I) YE $0.0+\left(\mathrm{NH}_{4}\right)_{2} \mathrm{SO}_{4} 0.5+\mathrm{KH}_{2} \mathrm{PO}_{4} 1.0+\mathrm{MgCl}_{2} 0.1$, (II) $\mathrm{YE} 0.5+$ $\left(\mathrm{NH}_{4}\right)_{2} \mathrm{SO}_{4} 0.5+\mathrm{KH}_{2} \mathrm{PO}_{4} 1.0+\mathrm{MgCl}_{2} 0.1$, (III) $\mathrm{YE} 0.5+\left(\mathrm{NH}_{4}\right)_{2} \mathrm{SO}_{4} 0.1+$ $\mathrm{KH}_{2} \mathrm{PO}_{4} 1.0+\mathrm{MgCl}_{2} 0.1$, (IV)YE $1.0+\left(\mathrm{NH}_{4}\right)_{2} \mathrm{SO}_{4} 0.5+\mathrm{KH}_{2} \mathrm{PO}_{4} 1.0+\mathrm{MgCl}_{2}$ 0.1 , (V)YE $1.0+\left(\mathrm{NH}_{4}\right)_{2} \mathrm{SO}_{4} 0.1+\mathrm{KH}_{2} \mathrm{PO}_{4} 1.0+\mathrm{MgCl}_{2} 0.1$ and (VI)YE $1.0+$ $\left(\mathrm{NH}_{4}\right)_{2} \mathrm{SO}_{4} 0.1+\mathrm{KH}_{2} \mathrm{PO}_{4} 0.1+\mathrm{MgCl}_{2} 0.1$ (control). Conditions of bioethanol production were carried out as previously mentioned. The medium formula that achieved the highest bioethanol concentration was used in bioreactor cultivations with a final working volume of 5 liters.

\section{Bioreactor conditions}

The bioreactor described above was used for bioethanol production in batch, pulsed fed-batch, continuous feeding and continuous cultivations with additional assembly of a multi-channel peristaltic pump (for feeding) and all the accessories for continuous cultivation. In all cases, the final working volume was 5 liters. In batch culture, the medium ( 5 liters) of filtered hydrolysate, derived from the fungal biotreatment of rice straw according to the conditions previously mentioned, was added totally to bioreactor before sterilization, while in pulsed fed-batch cultivation the medium (5 liters) was divided to equal amounts and added to fermentation vessel at $3 \mathrm{~h}$ intervals during $33 \mathrm{~h}$ of cultivation period. In continuous feeding, the medium was fed continuously during the first $33 \mathrm{~h}$ of cultivation at a constant addition rate of $151.5 \mathrm{ml} / \mathrm{h}$. The temperature was controlled at $30^{\circ} \mathrm{C}$, whereas $\mathrm{pH}$ was controlled at 5.5 with $2 \mathrm{~N} \mathrm{NaOH}$ during fermentation. Samples $(10 \mathrm{ml})$ were taken from the growing culture periodically under aseptic conditions to determine bioethanol and sugars concentrations.

In continuous culture, the cultivation was carried out as batch culture for $48 \mathrm{~h}$ at $30^{\circ} \mathrm{C}$ then fresh medium was pumped to growing culture at different flow rates of $50,100,150$ and $200 \mathrm{ml} / \mathrm{h}$ to give $0.01,0.02,0.03$ and $0.04 \mathrm{~h}^{-1}$ dilution rates, respectively. Appropriate culture volumes were withdrawn from the fermentation vessel at a given time to keep the total volume of culture constant at five liters. 
Each steady state was kept running for at least four days intervals. Three samples were taken aseptically at each steady state to determine bioethanol concentration and average response was calculated.

Statistical analysis

Duncan`s Multiple Range Test was used to test significance of means according to IBM ${ }^{\circledR}$ SPSS $^{\circledR}$ statistics software (IBM, 2011).

\section{Results and Discussion}

It is evident the importance of lignocellulosic biomass as a feedstock for bioethanol production. The main processing challenge in producing bioethanol from lignocellulosic biomass is the feedstock pretreatment. In our previous work (El-Tayeb et al., 2012), it was observed that fungal biotreatment of agroindustrial wastes may be a useful tool for lowering the production costs of bioethanol from lignocellulosic feedstocks comparing with acid hydrolysis treatments. Besides that, the biotreatment of different feedstocks led to a decrease in the final bioethanol concentration comparing with acid hydrolysis treatments (El-Tayeb et al., 2012). Attempts to increase the final bioethanol concentration on fungal biotreated lignocellulosic feedstocks were examined throughout this investigation.

\section{Pretreatment of agro-industrial wastes before fungal biotreatment}

In the present study, pretreatment with $5 \% \mathrm{w} / \mathrm{v} \mathrm{NaOH}, 1 \% \mathrm{v} / \mathrm{v} \mathrm{H}_{2} \mathrm{SO}_{4}$ and with sodium hypochlorite: $\mathrm{H}_{2} \mathrm{O}_{2}(10: 1)$ were compared separately on different agro-industrial wastes before the fungal biotreatment by Trichoderma viride EMCC 107. In general, the pretreatment with sodium hypochlorite: $\mathrm{H}_{2} \mathrm{O}_{2}$ (10:1) significantly increased the conversion percentage of agro-industrial wastes to total sugars, compared to control (without pretreatment), which reflected on enhancing the bioethanol production process. This pretreatment achieved the highest bioethanol concentration on all agro-industrial wastes comparing with control (Table 1). The highest bioethanol concentration $(0.55 \% \mathrm{v} / \mathrm{v})$ was obtained on sugar beet waste $(5 \% \mathrm{w} / \mathrm{v})$ pretreated with sodium hypochlorite: $\mathrm{H}_{2} \mathrm{O}_{2}(10: 1)$, followed by sugarcane baggase $(5 \% \mathrm{w} / \mathrm{v})$ influenced with the same pretreatment $(0.52 \% \mathrm{v} / \mathrm{v})$. These records increased bioethanol concentration by $25 \%$ and $26.8 \%$, respectively comparing with control. The effect of the other pretreatments varied greatly. The pretreatment with $5 \% \mathrm{NaOH}$ or $1 \% \mathrm{v} / \mathrm{v}$ $\mathrm{H}_{2} \mathrm{SO}_{4}$ decreased significantly the final bioethanol concentration in most cases. Accordingly, pretreatment of rice straw with sodium hypochlorite: $\mathrm{H}_{2} \mathrm{O}_{2}$ (10:1) was conducted throughout the rest of this investigation.

Many authors have reported various kinds of pretreatments of different agroindustrial wastes prior to hydrolysis process for obtainment of fermentable sugars for bioethanol production. Shrestha et al. (2009) pretreated corn fiber with $2 \%$ $\mathrm{NaOH}(\mathrm{w} / \mathrm{w})$ at $30^{\circ} \mathrm{C}$ for $2 \mathrm{~h}$. This pretreatment resulted in higher glucose yields following fungal saccharification of corn fiber. Bioethanol yields were $2.6 \mathrm{~g}, 2.9 \mathrm{~g}$

Egypt. J.Microbiol. 49 (2014) 
and $5.5 \mathrm{~g}$ bioethanol / $100 \mathrm{~g}$ of corn fiber, from Phanerochaete chrysosporium, Gloeophyllum trabeum and T. reesei, respectively. Kang et al. (2011) pretreated rice straw using a solution containing $0.6 \%$ hypochlorite and $25 \%$ hydrogen peroxide to obtain $406.8 \mathrm{mg}$ D-glucose and $224.0 \mathrm{mg}$ D-xylose from $1 \mathrm{~g}$ of rice straw. The fermentation of enzymatic hydrolysates containing $8.14 \mathrm{~g} / \mathrm{l} \mathrm{D}$-glucose and $4.49 \mathrm{~g} / \mathrm{l}$ d-xylose with Pichia stipitis generated $3.65 \mathrm{~g} / \mathrm{l}$ of bioethanol with a corresponding yield of $0.37 \mathrm{~g} / \mathrm{g}$. The maximum possible bioethanol conversion rate was $72.54 \%$. Lin \& Lee (2011) pretreated the sticks of rice straw with $10 \%$ $\mathrm{NaOH}$ at room temperature prior to enzymatic hydrolysis and bioethanol production. Bioethanol production on alkali pretreated rice straw at $40^{\circ} \mathrm{C}$ produced a bioethanol concentration of $29 \mathrm{~g} / \mathrm{l}$ and a bioethanol yield of $86 \%$ (based on glucose content in the pretreated raw material) in a $72 \mathrm{~h}$ reaction.

TABLE 1. Effect of pretreatment of agro-industrial wastes before fungal biotreatment on their conversion percentage to total sugars and the equivalent bioethanol production by baker's yeast using shake flasks technique.

\begin{tabular}{|c|c|c|c|}
\hline $\begin{array}{c}\text { Agro- } \\
\text { industrial } \\
\text { wastes } \\
(5 \% \mathrm{w} / \mathrm{v})\end{array}$ & $\begin{array}{c}\text { Pretreatment of } \\
\text { agro-industrial wastes } \\
\text { before fungal biotreatment }\end{array}$ & $\begin{array}{c}\text { Conversion percentage } \\
\text { of agro-industrial wastes } \\
\text { to total sugars } \\
(\% \mathrm{w} / \mathrm{w})^{*}\end{array}$ & $\begin{array}{c}\text { Bioethanol } \\
\text { concentration } \\
(\% \mathrm{v} / \mathrm{v})\end{array}$ \\
\hline \multirow{4}{*}{ Rice straw } & $5 \% \mathrm{w} / \mathrm{v} \mathrm{NaOH}$ & $10.8^{\mathrm{n}}$ & $0.08^{\mathrm{fg}}$ \\
\hline & $1 \% \mathrm{v} / \mathrm{v} \mathrm{H}_{2} \mathrm{SO}_{4}$ & $12.5^{1}$ & $0.1^{\mathrm{f}}$ \\
\hline & $\mathrm{NaClO}: \mathrm{H}_{2} \mathrm{O}_{2}(10: 1)$ & $17.3^{\mathrm{h}}$ & $0.3^{\mathrm{c}}$ \\
\hline & Control & $12.1^{1}$ & $0.2^{\mathrm{e}}$ \\
\hline \multirow{4}{*}{ Corn stalks } & $5 \% \mathrm{w} / \mathrm{v} \mathrm{NaOH}$ & $9.2^{\circ}$ & $0.05^{\mathrm{h}}$ \\
\hline & $1 \% \mathrm{v} / \mathrm{v} \mathrm{H}_{2} \mathrm{SO}_{4}$ & $12.2^{1}$ & $0.09^{\mathrm{f}}$ \\
\hline & $\mathrm{NaClO}: \mathrm{H}_{2} \mathrm{O}_{2}(10: 1)$ & $19.1^{\mathrm{g}}$ & $0.32^{\mathrm{c}}$ \\
\hline & Control & $13.2^{\mathrm{j}}$ & $0.1^{\mathrm{f}}$ \\
\hline \multirow{4}{*}{ Sawdust } & $5 \% \mathrm{w} / \mathrm{v} \mathrm{NaOH}$ & $10.4^{\mathrm{n}}$ & $0.05^{\mathrm{h}}$ \\
\hline & $1 \% \mathrm{v} / \mathrm{v} \mathrm{H}_{2} \mathrm{SO}_{4}$ & $11.7^{\mathrm{m}}$ & $0.08^{g}$ \\
\hline & $\mathrm{NaClO}: \mathrm{H}_{2} \mathrm{O}_{2}(10: 1)$ & $13.1^{\mathrm{k}}$ & $0.1^{\mathrm{f}}$ \\
\hline & Control & $9.5^{\circ}$ & $0.05^{\mathrm{h}}$ \\
\hline \multirow{4}{*}{$\begin{array}{l}\text { Sugar beet } \\
\text { waste }\end{array}$} & $5 \% \mathrm{w} / \mathrm{v} \mathrm{NaOH}$ & $30.4^{\mathrm{d}}$ & $0.22^{\mathrm{e}}$ \\
\hline & $1 \% \mathrm{v} / \mathrm{v} \mathrm{H}_{2} \mathrm{SO}_{4}$ & $31.3^{\mathrm{c}}$ & $0.25^{\mathrm{d}}$ \\
\hline & $\mathrm{NaClO}: \mathrm{H}_{2} \mathrm{O}_{2}(10: 1)$ & $39.5^{\mathrm{a}}$ & $0.55^{\mathrm{a}}$ \\
\hline & Control & $21.2^{\mathrm{f}}$ & $0.44^{\mathrm{b}}$ \\
\hline \multirow{4}{*}{$\begin{array}{c}\text { Sugarcane } \\
\text { bagasse }\end{array}$} & $5 \% \mathrm{w} / \mathrm{v} \mathrm{NaOH}$ & $15^{\mathrm{i}}$ & $0.18^{\mathrm{ef}}$ \\
\hline & $1 \% \mathrm{v} / \mathrm{v} \mathrm{H}_{2} \mathrm{SO}_{4}$ & $32.1^{\mathrm{b}}$ & $0.23^{\mathrm{e}}$ \\
\hline & $\mathrm{NaClO}: \mathrm{H}_{2} \mathrm{O}_{2}(10: 1)$ & $30.3^{\mathrm{d}}$ & $0.52^{\mathrm{a}}$ \\
\hline & Control & $22.4^{\mathrm{e}}$ & $0.41^{\mathrm{c}}$ \\
\hline
\end{tabular}

$*(\% \mathrm{w} / \mathrm{w})=$ percentage based on dry weight.

Control $=$ agro-industrial wastes without pretreatment.

The values are mean of three replicates. Standard deviation was within $10 \%$.

Values in the same column followed by the same letter(s) do not significantly differ from each other according to Duncan's at $5 \%$ level. 
Optimization of medium composition for bioethanol formation

A great number of microorganisms are capable of bioethanol formation on different productive media among which Sacch. cerevisiae (baker's yeast) is the most frequently and traditionally used organism (Barcelos et al., 2011). For the optimization of medium used for bioethanol production by baker's yeast, five different modifications were tested by changing the concentrations of medium components added to the filtered fungal hydrolysate obtained previously by the growth of $T$. viride EMCC 107 on $5 \% \mathrm{w} / \mathrm{v}$ rice straw (Table 2). The highest final bioethanol concentration was obtained in a medium containing the following components $(\mathrm{g} / 100 \mathrm{ml})$ : yeast extract $1.0,\left(\mathrm{NH}_{4}\right)_{2} \mathrm{SO}_{4} 0.5, \mathrm{KH}_{2} \mathrm{PO}_{4} 1.0$ and $\mathrm{MgCl}_{2}$ 0.1 . This modification increased bioethanol concentration $(0.36 \% \mathrm{v} / \mathrm{v})$ by $24.1 \%$ comparing with control and was applied for the further experiments. Most other combinations of productive medium nutrients decreased significantly final bioethanol concentration comparing with control. Several authors used many bioethanol producing organisms on different productive media. Rajoka et al. (2005) reported bioethanol productivity $(7.2 \mathrm{~g} / \mathrm{l} / \mathrm{h})$, product yield $(0.44 \mathrm{~g}$ bioethanol/g substrate utilized) and specific bioethanol yield (19.0 g bioethanol/g cells) in a medium containing molasses (15\% reducing sugars) and the following nutrients $(\mathrm{g} / \mathrm{l})$ : $\left(\mathrm{NH}_{4}\right)_{2} \mathrm{SO}_{4}, 2.5 ; \mathrm{MgSO}_{4}, 1.0$ and $\mathrm{KH}_{2} \mathrm{PO}_{4}, 2.0$ by Sacch. cerevisiae ATCC 26602 in a completely controlled bioreactor. In another study, batch bioethanol fermentation was carried out on sweet sorghum juice by Sacch. cerevisiae NP 01 in a $500 \mathrm{ml}$ air-locked conical flask. The maximum bioethanol production efficiency was obtained when $9 \mathrm{~g} / \mathrm{l}$ of yeast extract was supplemented to the juice. The bioethanol concentration, productivity and yield were $120.24 \mathrm{~g} / \mathrm{l}, 3.01 \mathrm{~g} / \mathrm{l} / \mathrm{h}$ and 0.49 , respectively (Nuanpeng et al., 2011). Landaeta et al. (2013) used a base medium contained (g/l): glucose 25, yeast extract 1, $\mathrm{KH}_{2} \mathrm{PO}_{4} 1,\left(\mathrm{NH}_{4}\right)_{2} \mathrm{SO}_{4} 0.4$ and $\mathrm{MgSO}_{4} 7 \mathrm{H}_{2} \mathrm{O} 0.08$ for bioethanol production $(0.48 \mathrm{~g} / \mathrm{l} / \mathrm{h})$ by Sacch. cerevisiae (NRRL Y-265). Maruthai et al. (2012) studied the effect of medium components (a total of fifteen components) on bioethanol production from waste cashew apple juice using yeast Sacch. diasticus. In general, initial substrate concentration significantly influenced the microbial growth and product formation. Of the medium components evaluated, yeast extract, $\left(\mathrm{NH}_{4}\right)_{2} \mathrm{SO}_{4}$, and malt extract showed significant effect on ethanol fermentation. Maximum bioethanol (15.3 g/l) was obtained at the optimum medium composition.

\section{Bioethanol production in bioreactor}

Rice straw is an attractive lignocellulosic material for bioethanol production since it is one of the most abundant renewable resources. It has several characteristics, such as high cellulose and hemicelluloses content that can be readily hydrolysed into fermentable sugars. According to the data obtained in the current work, rice straw was chosen as the most considerable cellulosic material for bioethanol production. The two stages of bioethanol production, which consisted of feedstock degradation and bioethanol fermentation, were conducted on rice straw to further optimization in batch, fed-batch (two strategies) and continuous cultures in bioreactor.

Egypt. J.Microbiol. 49 (2014) 
FUNGAL BIOTREATMENT OF AGRO-INDUSTRIAL WASTES...

TABLE 2. Enhancing bioethanol production by optimizing the composition of production medium containing rice straw hydrolysate* and inoculated with baker's yeast.

\begin{tabular}{|c|c|}
\hline $\begin{array}{c}\text { Nutrients supplemented to filtered rice straw hydrolysate } \\
\text { (bioethanol production medium) }(\mathbf{g} / \mathbf{1 0 0} \text { ml) }\end{array}$ & $\begin{array}{c}\text { Bioethanol } \\
\text { concentration } \\
(\% \text { v/v })\end{array}$ \\
\hline $\mathrm{YE} 0.0+\left(\mathrm{NH}_{4}\right)_{2} \mathrm{SO}_{4} 0.5+\mathrm{KH}_{2} \mathrm{PO}_{4} 1.0+\mathrm{MgCl}_{2} 0.1$ & $0.2^{\mathrm{f}}$ \\
$\mathrm{YE} 0.5+\left(\mathrm{NH}_{4}\right)_{2} \mathrm{SO}_{4} 0.5+\mathrm{KH}_{2} \mathrm{PO}_{4} 1.0+\mathrm{MgCl}_{2} 0.1$ & $0.25^{\mathrm{e}}$ \\
$\mathrm{YE} 0.5+\left(\mathrm{NH}_{4}\right)_{2} \mathrm{SO}_{4} 0.1+\mathrm{KH}_{2} \mathrm{PO}_{4} 1.0+\mathrm{MgCl}_{2} 0.1$ & $0.28^{\mathrm{d}}$ \\
$\mathrm{YE} 1.0+\left(\mathrm{NH}_{4}\right)_{2} \mathrm{SO}_{4} 0.5+\mathrm{KH}_{2} \mathrm{PO}_{4} 1.0+\mathrm{MgCl}_{2} 0.1$ & $0.36^{\mathrm{a}}$ \\
$\mathrm{YE} 1.0+\left(\mathrm{NH}_{4}\right)_{2} \mathrm{SO}_{4} 0.1+\mathrm{KH}_{2} \mathrm{PO}_{4} 1.0+\mathrm{MgCl}_{2} 0.1$ & $0.31^{\mathrm{b}}$ \\
YE $1.0+\left(\mathrm{NH}_{4}\right)_{2} \mathrm{SO}_{4} 0.1+\mathrm{KH}_{2} \mathrm{PO}_{4} 0.1+\mathrm{MgCl}_{2} 0.1$ (control) & $0.29^{\mathrm{c}}$ \\
\hline
\end{tabular}

*Filtered hydrolysate $=$ obtained by the growth of $T$. viride EMCC 107 on $5 \% \mathrm{w} / \mathrm{v}$ rice straw in conical flasks.

YE $=$ Yeast extract.

Control $=$ original bioethanol production medium

The values are mean of three replicates. Standard deviation was within $10 \%$.

Values in the same column followed by the same letter(s) do not significantly differ from each other according to Duncan's at $5 \%$ level.

\section{Batch production}

Biodegradation of rice straw using the fungus T. viride EMCC 107 was conducted in submerged batch culture. The growth of the fungus increased greatly in bioreactor comparing with that obtained in conical flasks propagation. At the end of culturing period, the final conversion percentage of rice straw to total sugars was $22.2 \% \mathrm{w} / \mathrm{w}$, which was higher than that obtained in conical flasks experiments $(17.3 \% \mathrm{w} / \mathrm{w}$, Table 1$)$. Hydrolysate containing fermentable sugars was obtained by filtration of fungal culture and used for bioethanol production by baker's yeast in bioreactor. At the end of fermentation period, bioethanol concentration was $0.41 \% \mathrm{v} / \mathrm{v}$, which represented an increase by $13.89 \%$ comparing with that obtained in batch production in conical flasks $(0.36 \% \mathrm{v} / \mathrm{v}$, Table 2). This result indicated that rice straw degradation in bioreactor by $T$. viride EMCC 107 was higher than that obtained in conical flasks which also consequently reflected on increasing the final bioethanol concentration. The highest figures of conversion coefficient, bioethanol yield and productivity at the end of fermentation period, were $(36.9 \% \mathrm{v} / \mathrm{w}, 36.9 \% \mathrm{v} / \mathrm{w}$ and $0.114 \mathrm{ml} / \mathrm{l} / \mathrm{h}$, respectively). In a related work, Nuanpeng et al. (2011) scaled up batch bioethanol fermentation in a 5 liter bioreactor at an agitation rate of $100 \mathrm{rev} \mathrm{min}^{-1}$. They revealed that bioethanol concentration, productivity and yield were $139.51 \mathrm{~g} / \mathrm{l}$, $3.49 \mathrm{~g} / \mathrm{l} / \mathrm{h}$ and 0.49 , respectively. In another report, Sacch. cerevisiae was used for the production of bioethanol from sorghum grains hydrolysate $(250 \mathrm{~g} / \mathrm{l}$ glucose) in batch bioreactor. The maximum bioethanol concentration produced was $106 \mathrm{~g} / \mathrm{l}$ in $24 \mathrm{~h}$, resulting in a productivity of $4.4 \mathrm{~g} / \mathrm{l} / \mathrm{h}$ and a product yield based on the substrate consumed $(0.499 \mathrm{~g} / \mathrm{g}$ ) (Barcelos et al., 2011). 


\section{Pulsed fed-batch and continuous feeding}

In fermentation processes, cell growth and/or product formation may be inhibited by substrate inhibitory materials concentrations, thus substrate is intermittently fed to the culture system in order to maintain the substrate concentration below a certain level for enhancement of biological and metabolic activity. Empirical feeding techniques of the filtered fungal hydrolysate of rice straw have been developed to improve the bioethanol production process. The optimization of feeding policy plays a crucial role for increasing both productivity and bioethanol yield of fed-batch fermentations. This issue was analyzed in a previous review (Cardona \& Sànchez, 2007). In present investigation, two feeding techniques, including pulsed and continuous feeding were conducted to determine the most efficient technique for high bioethanol production by baker's yeast. Pulsed addition of the filtered hydrolysate was carried out every three hours during two days of bioethanol production period (Table 3). Bioethanol concentration and consumed sugars increased gradually during fermentation period. At the end of fermentation period $(36-48 \mathrm{~h})$, the highest bioethanol concentration and bioethanol yield were obtained $(0.41 \% \mathrm{v} / \mathrm{v}$ and $36.9 \% \mathrm{v} / \mathrm{w}$, respectively), whereas, the highest productivity was recorded after $33 \mathrm{~h}(0.0115 \mathrm{ml} / \mathrm{/} / \mathrm{h})$. The maximum conversion coefficient $(39.7 \% \mathrm{v} / \mathrm{w})$ was obtained after $30 \mathrm{~h}$. Data in Table 4 show bioethanol production by baker's yeast grown on rice straw hydrolysate by continuous fed-batch culture at rate of 151.5 $\mathrm{ml} / \mathrm{h}$ during 2 days of fermentation. The maximum bioethanol concentration was obtained after $30 \mathrm{hr}$ of incubation $(0.45 \% \mathrm{v} / \mathrm{v})$. The corresponding figures of conversion coefficient, bioethanol yield and productivity were $40.5 \% \mathrm{v} / \mathrm{w}, 40.5$ $\mathrm{v} / \mathrm{w} \%$ and $0.015 \mathrm{ml} / \mathrm{/} / \mathrm{h}$, respectively. Bioethanol concentration was constant at $0.45 \% \mathrm{v} / \mathrm{v}$ throughout the last $18 \mathrm{~h}$ of fermentation period, while bioethanol productivity was decreasing throughout this period. Generally, it could be concluded that the continuous feeding at $151.5 \mathrm{ml} / \mathrm{h}$ during 2 days, was favorable for high bioethanol production than that recorded in pulsed feeding technique. In spite of the low concentration of sugars in the feeding liquor which sometimes discourages the strategy of fed-batch cultivation in general, this strategy increased the final bioethanol concentration which might be due to lowering of some inhibitory materials in liquor. In a previous report, bioethanol fermentation of sunflower seed hull hydrolysate was carried out in a batch bioreactor system using Pichia stipitis NRRLY-7124. The highest bioethanol accumulation, 9.66 $\mathrm{g} / \mathrm{l}$, and a yield of $0.41 \mathrm{~g} / \mathrm{g}$ were achieved at the lowest tested flow rate, 2.28 /vv/min, from $35 \mathrm{~g} / \mathrm{l}$ reducing sugars (Okur \& Saraçoğlu, 2006). Kumoro et al. (2009) investigated the effect of different glucose feeding rates on bioethanol fermentation in fed-batch culture. The $2 \mathrm{~g} / \mathrm{l} / \mathrm{h}$ glucose concentration feeding rate gave higher bioethanol yield ( $2.47 \mathrm{~g}$ bioethanol / $\mathrm{g}$ glucose), with respect to substrate consumed, as compared to $8 \mathrm{~g} / \mathrm{l} / \mathrm{h}(0.23 \mathrm{~g}$ bioethanol $/ \mathrm{g}$ glucose $)$. In batch culture, bioethanol yield was $0.81 \mathrm{~g} / \mathrm{g}$ glucose. The specific glucose consumption rate and specific bioethanol production rate for the fed-batch fermentation, at $2 \mathrm{~g} / \mathrm{l} / \mathrm{h}$ glucose feeding rate, were $1.20 \mathrm{~h}^{-1}$ and $0.0009 \mathrm{~h}^{-1}$, respectively. 
FUNGAL BIOTREATMENT OF AGRO-INDUSTRIAL WASTES...

TABLE 3. Time course of bioethanol production by baker's yeast in a pulsed fedbatch culture with filtered fungal hydrolysate obtained by the growth of T. viride $\mathrm{EMCC} 107$ on $5 \% \mathrm{w} / \mathrm{v}$ rice straw in bioreactor.

\begin{tabular}{|c|c|c|c|c|c|c|c|c|}
\hline$\stackrel{\mathscr{\Xi}}{\Xi}$ & 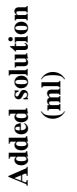 & 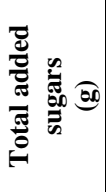 & 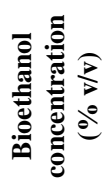 & 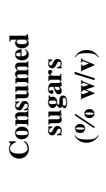 & 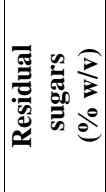 & 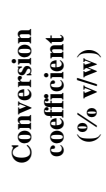 & 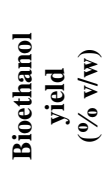 & 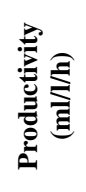 \\
\hline 0 & 625 & 6.93 & 0.0 & 0.0 & 1.11 & - & - & - \\
\hline 3 & 625 & 13.87 & 0.011 & 0.05 & 1.06 & 22 & 0.9 & 0.0037 \\
\hline 6 & 625 & 20.79 & 0.042 & 0.14 & 0.96 & 30 & 3.7 & 0.007 \\
\hline 9 & 625 & 27.72 & 0.08 & 0.21 & 0.91 & 38 & 7.2 & 0.0089 \\
\hline 24 & 625 & 34.65 & 0.15 & 0.42 & 0.68 & 35.7 & 13.5 & 0.0063 \\
\hline 27 & 625 & 41.58 & 0.21 & 0.57 & 0.53 & 36.8 & 18.9 & 0.0078 \\
\hline 30 & 625 & 48.51 & 0.29 & 0.73 & 0.36 & 39.7 & 26.1 & 0.0097 \\
\hline 33 & 625 & 55.44 & 0.38 & 1.08 & 0.01 & 35.2 & 34.2 & 0.0115 \\
\hline 36 & 0.0 & 55.44 & 0.41 & 1.11 & 0.0 & 36.9 & 36.9 & 0.0114 \\
\hline 48 & 0.0 & 55.44 & 0.41 & 1.11 & 0.0 & 36.9 & 36.9 & 0.0085 \\
\hline
\end{tabular}

The values are mean of three samples determinations. Standard deviation was within $5 \%$.

Added sugars concentration at each time interval $=1.11 \% \mathrm{w} / \mathrm{v}$.

Conversion coefficient $(\%)=$ amount of bioethanol produced $(\% \mathrm{w} / \mathrm{v}) \times 100 /$ sugars consumed $(\% \mathrm{w} / \mathrm{v})$ (Gamal et al., 2013).

Bioethanol yield $(\%)=$ amount of bioethanol produced $(\% \mathrm{v} / \mathrm{v}) \times 100 /$ initial sugars concentration $(\% \mathrm{w} / \mathrm{v})$ (Gamal et al., 2013).

Productivity $(\mathrm{P})=$ amount of bioethanol produced $(\% \mathrm{v} / \mathrm{v}) /$ fermentation time $(\mathrm{h})=\mathrm{ml} / \mathrm{/} / \mathrm{h}(\mathrm{Gamal}$ et al., 2013).

TABLE 4. Time course of bioethanol production by baker's yeast in a continuous fed-batch culture (specific addition rate at $151.5 \mathrm{ml} / \mathrm{h}$ ) with filtered fungal hydrolysate obtained by the growth of T. viride EMCC 107 on $5 \%$ w/v rice straw in bioreactor.

\begin{tabular}{|c|c|c|c|c|c|c|c|c|}
\hline$\stackrel{\mathscr{\Xi}}{\Xi}$ & 월 & 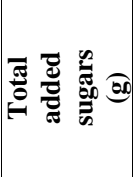 & 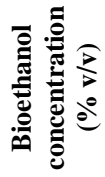 & 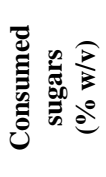 & 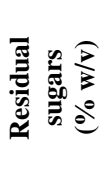 & 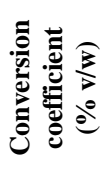 & 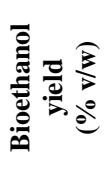 & 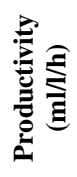 \\
\hline 0 & 0.0 & 0.0 & 0.0 & 0.0 & 1.11 & - & - & - \\
\hline 3 & 714.3 & 7.93 & 0.04 & 0.11 & 0.99 & 36.4 & 3.6 & 0.013 \\
\hline 6 & 1428.6 & 15.8 & 0.12 & 0.28 & 0.81 & 42.9 & 10.8 & 0.02 \\
\hline 9 & 2142.9 & 23.8 & 0.21 & 0.55 & 0.55 & 38.2 & 18.9 & 0.023 \\
\hline 24 & 2857.2 & 31.7 & 0.31 & 0.75 & 0.34 & 41.3 & 27.9 & 0.013 \\
\hline 27 & 3571.5 & 39.6 & 0.39 & 0.95 & 0.13 & 41.0 & 35.1 & 0.014 \\
\hline 30 & 4285.8 & 47.6 & 0.45 & 1.11 & 0.0 & 40.5 & 40.5 & 0.015 \\
\hline 33 & 5000 & 55.5 & 0.45 & 1.11 & 0.0 & 40.5 & 40.5 & 0.014 \\
\hline 36 & 0.0 & 0.0 & 0.45 & 1.11 & 0.0 & 40.5 & 40.5 & 0.013 \\
\hline 48 & 0.0 & 0.0 & 0.45 & 1.11 & 0.0 & 40.5 & 40.5 & 0.009 \\
\hline
\end{tabular}

The values are mean of three samples determinations. Standard deviation was within $5 \%$.

Added sugars concentration at each time interval $=1.11 \% \mathrm{w} / \mathrm{v}$.

Conversion coefficient $(\%)=$ amount of bioethanol produced $(\% \mathrm{v} / \mathrm{v}) \times 100 /$ sugars consumed $(\%$ w/v) (Gamal et al., 2013).

Bioethanol yield $(\%)=$ amount of bioethanol produced $(\% \mathrm{v} / \mathrm{v}) \times 100 /$ initial sugars concentration (\% w/v) (Gamal et al., 2013).

Productivity $(\mathrm{P})=$ amount of bioethanol produced $(\% \mathrm{v} / \mathrm{v}) /$ fermentation time $(\mathrm{h})=\mathrm{ml} / \mathrm{l} / \mathrm{h}(\mathrm{Gamal}$ et al., 2013). 


\section{Continuous culture}

The design and development of continuous fermentation systems have allowed the implementation of more cost effective processes. Continuous processes have several advantages compared to conventional batch processes mainly due to the reduced construction costs of the bioreactors, lower maintenance and operation requirements, better process control, and higher productivities.

Bioethanol production by baker's yeast was studied in continuous culture at different dilution rates (steady states $0.01,0.02,0.03$ and $0.04 \mathrm{~h}^{-1}$ ) in bioreactor. Bioethanol production and productivity were expressed as a function of dilution rates. The filtered rice straw hydrolysate was added to the bioreactor at different flow rates ranged from 50 to $200 \mathrm{ml} / \mathrm{h}$, after $48 \mathrm{~h}$ of incubation. Results in Tables $5,6,7$ and 8 show that variation in dilution rate, resulted in changes in the steady state of conversion coefficient, bioethanol yield and productivity. Bioethanol concentration increased with increasing dilution rate from $0.01 \mathrm{~h}^{-1}$ to $0.03 \mathrm{~h}^{-1}$ and remained constant for four days, while washing out was observed at $0.04 \mathrm{~h}^{-1}$. Bioethanol concentration outlet ranged from 0.155 to $0.185 \mathrm{ml} / \mathrm{h}$ at dilution rate $0.01 \mathrm{~h}^{-1}$, whereas they ranged from 0.44 to $0.48 \mathrm{ml} / \mathrm{h}$ at dilution rate $0.02 \mathrm{~h}^{-1}$. The mean value of the highest amount of bioethanol concentration outlet $(0.765 \mathrm{ml} / \mathrm{h})$ was attained at $0.03 \mathrm{~h}^{-1}$ dilution rate. At $0.04 \mathrm{~h}^{-1}$ dilution rate, where no steady state was observed, bioethanol concentration outlet was decreased from 0.38 to $0.02 \mathrm{ml} / \mathrm{h}$, during four days of incubation period. Sugars input were $0.555,1.11$, 1.665 , and $2.22 \mathrm{~g} / \mathrm{h}$ for $0.01,0.02,0.03$ and $0.04 \mathrm{~h}^{-1}$ dilution rates, respectively. Consumed sugars $(\mathrm{g} / \mathrm{h})$ at different dilution rates were increased with the increase of sugars input till $0.03 \mathrm{~h}^{-1}$. Conversion coefficient, bioethanol yield and bioethanol productivity were increased with increasing of dilution rate (sugars input), reaching the maximum at $0.03 \mathrm{~h}^{-1}(30.6 \% \mathrm{v} / \mathrm{w}, 30.8 \% \mathrm{v} / \mathrm{w}$ and 0.021 $\mathrm{ml} / \mathrm{l} / \mathrm{h}$, respectively), then decreased at $0.04 \mathrm{~h}^{-1}$ dilution rate (where no steady state was observed). Accordingly, it could be stated that the maximum dilution rate to be used, is $0.03 \mathrm{~h}^{-1}$ for giving maximum bioethanol productivity.

TABLE 5. Bioethanol production by baker's yeast in continuous culture at $0.01 \mathbf{h}^{-1}$ dilution rate $(50 \mathrm{ml}$ filtered hydrolysate* / h flow rate / $5000 \mathrm{ml}$ culture).

\begin{tabular}{|c|c|c|c|c|c|c|c|c|}
\hline 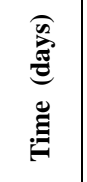 & 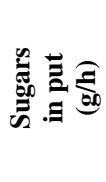 & 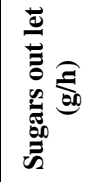 & 胥 & 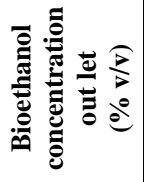 & 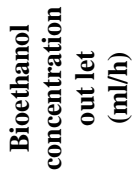 & 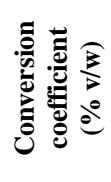 & 总 & 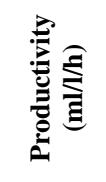 \\
\hline 1 & 0.555 & 0.002 & 0.553 & 0.37 & 0.185 & 66.9 & 66.67 & 0.015 \\
\hline 2 & 0.555 & 0.001 & 0.552 & 0.35 & 0.175 & 63.4 & 63.06 & 0.014 \\
\hline 3 & 0.555 & 0.002 & 0.553 & 0.32 & 0.16 & 57.8 & 57.66 & 0.013 \\
\hline 4 & 0.555 & 0.001 & 0.554 & 0.31 & 0.155 & 55.9 & 55.86 & 0.013 \\
\hline Means & 0.555 & 0.0015 & 0.553 & 0.3375 & 0.169 & 61 & 60.81 & 0.01375 \\
\hline
\end{tabular}

*Filtered hydrolysate $=$ obtained by the growth of $T$. viride $\mathrm{EMCC} 107 \mathrm{on} 5 \% \mathrm{w} / \mathrm{v}$ rice straw in bioreactor. The values are mean of three samples determinations. Standard deviation was within $5 \%$.

Conversion coefficient $(\%)=$ amount of bioethanol produced $(\% \mathrm{v} / \mathrm{v}) \times 100 /$ sugars consumed $(\% \mathrm{w} / \mathrm{v})$ (Gamal et al., 2013).

Bioethanol yield $(\%)=$ amount of bioethanol produced $(\% \mathrm{v} / \mathrm{v}) \times 100 /$ initial sugars concentration $(\% \mathrm{w} / \mathrm{v})$ (Gamal et al., 2013).

Productivity $(\mathrm{P})=$ amount of bioethanol produced $(\% \mathrm{v} / \mathrm{v}) /$ fermentation time $(\mathrm{h})=\mathrm{ml} / \mathrm{l} / \mathrm{h}($ Gamal et al., 2013).

Egypt. J.Microbiol. 49 (2014) 
FUNGAL BIOTREATMENT OF AGRO-INDUSTRIAL WASTES ...

TABLE 6. Bioethanol production by baker's yeast in continuous culture at $0.02 \mathrm{~h}^{-1}$ dilution rate (100 ml filtered hydrolysate* / h flow rate / $5000 \mathrm{ml}$ culture).

\begin{tabular}{|c|c|c|c|c|c|c|c|c|}
\hline 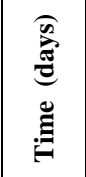 & 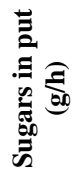 & 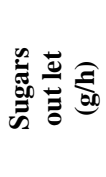 & 总 & 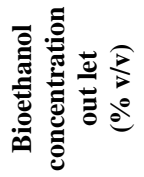 & 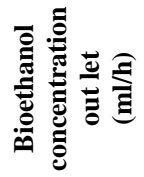 & 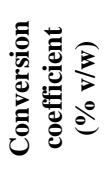 & 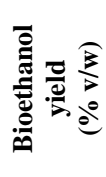 & 疍 \\
\hline 1 & 1.11 & 0.004 & 1.106 & 0.48 & 0.48 & 43.2 & 43.2 & 0.02 \\
\hline 2 & 1.11 & 0.005 & 1.105 & 0.46 & 0.46 & 41.4 & 41.4 & 0.019 \\
\hline 3 & 1.11 & 0.004 & 1.106 & 0.44 & 0.44 & 39.6 & 39.6 & 0.018 \\
\hline 4 & 1.11 & 0.006 & 1.106 & 0.46 & 0.46 & 41.4 & 41.4 & 0.019 \\
\hline Means & 1.11 & 0.0048 & 1.1058 & 0.46 & 0.46 & 41.4 & 41.4 & 0.019 \\
\hline
\end{tabular}

*Filtered hydrolysate $=$ obtained by the growth of $T$. viride EMCC 107 on $5 \% \mathrm{w} / \mathrm{v}$ rice straw in bioreactor.

The values are mean of three samples determinations. Standard deviation was within $5 \%$.

Conversion coefficient $(\%)=$ amount of bioethanol produced $(\% \mathrm{v} / \mathrm{v}) \times 100 /$ sugars consumed $(\% \mathrm{w} / \mathrm{v})$ (Gamal et al., 2013).

Bioethanol yield $(\%)=$ amount of bioethanol produced $(\% \mathrm{v} / \mathrm{v}) \times 100 /$ initial sugars concentration (\% w/v) (Gamal et al., 2013).

Productivity $(\mathrm{P})=$ amount of bioethanol produced $(\% \mathrm{v} / \mathrm{v}) /$ fermentation time $(\mathrm{h})=\mathrm{ml} / \mathrm{l} / \mathrm{h}$ (Gamal et al., 2013).

TABLE 7. Bioethanol production by baker's yeast in continuous culture at $0.03 \mathrm{~h}^{-1}$ dilution rate $(150 \mathrm{ml}$ filtered hydrolysate* / h flow rate / $5000 \mathrm{ml}$ culture).

\begin{tabular}{|c|c|c|c|c|c|c|c|c|}
\hline 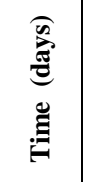 & 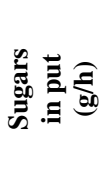 & 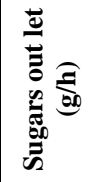 & 冚 & 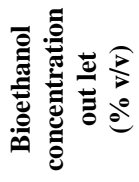 & 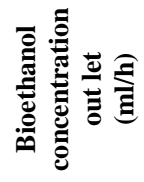 & 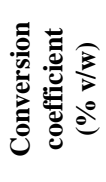 & 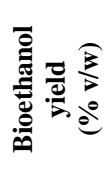 & 疍 \\
\hline 1 & 1.665 & 0.007 & 1.658 & 0.49 & 0.735 & 29.4 & 29.6 & 0.02 \\
\hline 2 & 1.665 & 0.008 & 1.657 & 0.51 & 0.765 & 30.6 & 30.8 & 0.021 \\
\hline 3 & 1.665 & 0.01 & 1.655 & 0.52 & 0.78 & 31.2 & 31.4 & 0.022 \\
\hline 4 & 1.665 & 0.01 & 1.655 & 0.52 & 0.78 & 31.2 & 31.4 & 0.022 \\
\hline Means & 1.665 & 0.0088 & 1.656 & 0.51 & 0.765 & 30.6 & 30.8 & 0.021 \\
\hline
\end{tabular}

*Filtered hydrolysed $=$ obtained by the growth of $T$. viride EMCC 107 on $5 \% \mathrm{w} / \mathrm{v}$ rice straw in bioreactor.

The values are mean of three samples determinations. Standard deviation was within $5 \%$.

Conversion coefficient $(\%)=$ amount of bioethanol produced $(\% \mathrm{v} / \mathrm{v}) \times 100 /$ sugars consumed (\% w/v) (Gamal et al., 2013).

Bioethanol yield $(\%)=$ amount of bioethanol produced $(\% \mathrm{v} / \mathrm{v}) \times 100 /$ initial sugars concentration (\% w/v) (Gamal et al., 2013).

Productivity $(\mathrm{P})=$ amount of bioethanol produced $(\% \mathrm{v} / \mathrm{v}) /$ fermentation time $(\mathrm{h})=\mathrm{ml} / \mathrm{l} / \mathrm{h}(\mathrm{Gamal}$ et al., 2013). 
TABLE 8. Bioethanol production by baker's yeast in continuous culture at $0.04 h^{-1}$ dilution rate $(200 \mathrm{ml}$ filtered hydrolysate* / h flow rate / $5000 \mathrm{ml}$ culture).

\begin{tabular}{|c|c|c|c|c|c|c|c|c|}
\hline 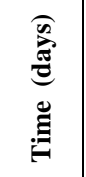 & 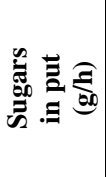 & 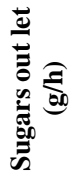 & 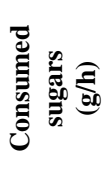 & 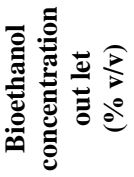 & 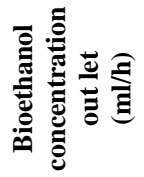 & 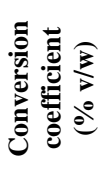 & 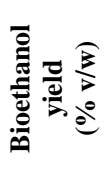 & 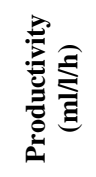 \\
\hline 1 & 2.22 & 0.6 & 1.62 & 0.19 & 0.38 & 11.7 & 8.5 & 0.008 \\
\hline 2 & 2.22 & 1.04 & 1.18 & 0.14 & 0.28 & 11.9 & 6.3 & 0.006 \\
\hline 3 & 2.22 & 1.62 & 0.6 & 0.06 & 0.12 & 10.0 & 2.7 & 0.003 \\
\hline 4 & 2.22 & 2.08 & 0.14 & 0.01 & 0.02 & 7.14 & 0.4 & 0.0004 \\
\hline Means & 2.22 & 1.335 & 0.885 & 0.1 & 0.2 & 10.185 & 4.475 & 0.00435 \\
\hline
\end{tabular}

*Filtered hydrolysate $=$ obtained by the growth of $T$. viride EMCC 107 on $5 \% \mathrm{w} / \mathrm{v}$ rice straw in bioreactor.

The values are mean of three samples determinations. Standard deviation was within $5 \%$.

Conversion coefficient $(\%)=$ amount of bioethanol produced $(\% \mathrm{v} / \mathrm{v}) \times 100 /$ sugars consumed (\% w/v) (Gamal et al., 2013).

Bioethanol yield $(\%)=$ amount of bioethanol produced $(\% \mathrm{v} / \mathrm{v}) \times 100 /$ initial sugars concentration (\% w/v) (Gamal et al., 2013).

Productivity $(\mathrm{P})=$ amount of bioethanol produced $(\% \mathrm{v} / \mathrm{v}) /$ fermentation time $(\mathrm{h})=\mathrm{ml} / \mathrm{l} / \mathrm{h}(\mathrm{Gamal}$ et al., 2013).

By comparing bioethanol formation parameters obtained by baker's yeast from biotreated rice straw by different fermentation techniques conducted in this investigation, it could be concluded that the highest bioethanol concentration and productivity was attained in continuous culture technique at $0.03 \mathrm{~h}^{-1}$ dilution rate $(0.51 \% \mathrm{v} / \mathrm{v}$ and $0.021 \mathrm{ml} / \mathrm{l} / \mathrm{h}$, respectively). While the maximum amount of bioethanol obtained by using fed-batch technique, was by the continuous addition of filtered rice straw hydrolysate at specific addition rate of $151.5 \mathrm{ml} / \mathrm{h}(0.45 \% \mathrm{v} / \mathrm{v})$ after $30 \mathrm{~h}$, followed by that obtained in pulsed fed-batch culture technique $(0.41 \%$ $\mathrm{v} / \mathrm{v})$ after $36 \mathrm{~h}$. Regarding the high productivity of continuous culture technique at $0.03 \mathrm{~h}^{-1}$ dilution rate, this method was considered as the most efficient for bioethanol production by baker's yeast on biodegraded rice straw using T. viride EMCC 107. In a related investigation, continuous bioethanol production was carried out using Sacch. cerevisiae and a medium containing $280 \mathrm{~g} / \mathrm{l}$ glucose. An average bioethanol concentration of $124.6 \mathrm{~g} / \mathrm{l}$ or $15.8 \%$ (v) was produced when the bioreactor system was operated at a dilution rate of $0.012 \mathrm{~h}^{-1}$. The yield of bioethanol to glucose consumed was calculated to be 0.484 (Bai et al., 2004). Saha \& Cotta (2011) produced bioethanol continuously with high productivity from alkaline peroxide pretreated and enzymatically saccharified wheat straw hydrolysate under various conditions at controlled $\mathrm{pH} 6.5$ and $35^{\circ} \mathrm{C}$. The average bioethanol produced from the available sugars $(21.9-47.8 \mathrm{~g} / \mathrm{l})$ ranged from 8.8 to $17.3 \mathrm{~g} / \mathrm{l}(0.28-0.45 \mathrm{~g} / \mathrm{g}$ available sugars, $0.31-0.48 \mathrm{~g} / \mathrm{g}$ sugars consumed) with bioethanol productivity of $0.27-0.78 \mathrm{~g} / \mathrm{l} / \mathrm{h}$ in a set of 14 continuous culture runs (16 -105 days). Whereas, encapsulated Sacch. cerevisiae was able to ferment dilute acid lignocellulosic hydrolysate in continuous culture to bioethanol at dilution rates up to $0.5 \mathrm{~h}^{-1}$ with a bioethanol yield of $0.44 \mathrm{~g} / \mathrm{g}$ and a specific productivity of $0.14-0.17 \mathrm{~g} / \mathrm{g} / \mathrm{h}$ (Talebnia

Egypt. J.Microbiol. 49 (2014) 
et al., 2006). Ali (2013) carried out continuous bioethanol production by Sacch cerevisiae in bioreactor. The conditions that gave the best bioethanol productivity $(7.57 \mathrm{~g} / \mathrm{l} / \mathrm{h})$ was found to be an initial date syrup sugar concentration of $5.5 \%(\mathrm{w} / \mathrm{v})$ and a feeding flow rate of $294 \mathrm{ml} / \mathrm{h}$.

\section{Conclusion}

In this study, the bioconversion of some lignocellulosic feedstocks to bioethanol was investigated. Our results revealed that fungal biotreatment of these pretreated feedstocks, especially rice straw, and the subsequent fermentation of obtained hydrolysates by baker's yeast had promising effects on increasing the overall bioethanol concentration. This research might play important role in bioethanol production and leave the door open on using some other feedstocks in studies similar to those conducted with rice straw. These data will also be helpful to construct a new approach for lignocellulosic bioethanol production in the future.

Acknowledgments : This work was funded by the STDF (Science and Technology Development Fund) provided by The Academy of Scientific Research and Technology in Egypt. Special cordial thanks to Dr. Ibrahim Abouleish and Dr. Kadria Abdel Motaal (Heliopolis University) for their cooperation and support.

\section{References}

Ali, H.Kh.Q. (2013) Compatibility of the flocculation of Saccharomyces uvarum and fermentation optimum conditions to improve ethanol production continuously using recycle tower bioreactor. Environ. Prog. Sustain. Energy, 1, 1-7.

AOAC (2007) Association of Official Analytical Chemists (now AOAC International). "Sugars and Sugars Products", $18^{\text {th }}$ ed., Chapter 44, p.11.

Bai, F.W., Chen, L.J., Zhang, Z.W., Anderson, A. and Moo-Young, M. (2004) Continuous ethanol production and evaluation of yeast cell lysis and viability loss under very high gravity medium conditions. J. Biotechnol. 110, 287-293.

Barcelos, C.A., Maeda, R.N., Betancur, G.J.V. and Pereira, Jr.N. (2011) Ethanol production from sorghum grains [Sorghum bicolor (L.) Moench]: evaluation of the enzymatic hydrolysis and the hydrolysate fermentability. Braz. J. Chem. Eng. 28, 597-604.

Cardona, C.A. and Sànchez, $\mathbf{O}^{\prime} . J$. (2007) Fuel ethanol production: process design trends and integration opportunities. Bioresour. Technol. 98, 2415-2457.

Choi, H.C., Kim, D., Kim, N.M., Kim, G., Kim, J.M., Kang, H.K. and Day, D.F. (2009) Rice Straw Oxidation Using Hypochlorite-Hydrogen Peroxide for Bioconversion to Ethanol. $31^{\text {th }}$ Symp Biotechnol Fuels Chem http://sim.confex.com/sim/31st/techprogram/P9755.HTM. 
El-Tayeb, T.S., Abdelhafez, A.A., Ali, S.H. and Ramadan, E.M. (2012) Effect of acid hydrolysis and fungal biotreatment on agro-industrial wastes for obtainment of free sugars for bioethanol production. Braz. J. Microbiol. 43, 1523-1535.

Gamal, R.F., Abdelhady, H.M., Hassan, E.A., El-Tayeb, T.S. and Aboutaleb, K.A. (2013) Semi-scale production of PHAs from waste frying oil by Pseudomonas fluorescens S48. Braz. J. Microbiol. 44, 539 - 549.

IBM® SPSS ${ }^{\circledR}$ Statistics (2011) Version 19.0, SPSS Inc., Chicago, Illinois.

Jakobsson, E.L. (2005) Optimization of the pretreatment of wheat straw for production of bioethanol. Department of Chemical Engineering, Lund University. http://www.chemeng.lth.se/exjobb/025.pdf.

Jessen, J.E. and Orlygsson, J. (2012) Production of ethanol from sugars and lignocellulosic biomass by Thermoanaerobacter $\mathrm{J} 1$ isolated from a hot spring in Iceland. J. Biomed. Biotechnol. 1,1-7.

Kang, H.K., Kim, N.M., Kim, G.J., Seo, E.S., Ryu, H.J., Yun, S.I., Choi, H.Ch., Day, D.F., Kim, J., Cho, D.L. and Kim, D. (2011) Enhanced saccharification of rice straw using hypochlorite-hydrogen peroxide. Biotechnol. Bioproc. Engin. 16, 273-281.

Kumoro, A.C., Ngoh, G.C., Hasan, M., Chew, F.L. and Tham, M. (2009) Production of ethanol by fed-batch fermentation. Pertanika J. Sci. Technol. 17, 399-408.

Landaeta, R., Aroca, G., Acevedo, F., Teixeira, J.A. and Mussatto, S.I. (2013) Adaptation of a flocculent Saccharomyces cerevisiae strain to lignocellulosic inhibitors by cell recycle batch fermentation. Appl. Energy, 102, 124-130.

Laopaiboon, L., Thanonkeo, P., Jaisil, P. and Laopaiboon, P. (2007) Ethanol production from sweet sorghum juice in batch and fed-batch fermentations by Saccharomyces cerevisiae. World J. Microbiol. Biotechnol. 23, 1497-1501.

Lau, O.W. and Luk, S.F. (1994) Spectrophotometric method for the determination of bioethanol in beverages and beer samples using cerium (IV) as reagent. Int. J. Food Sci. Technol. 29, 469-472.

Lin, Y.Sh. and Lee, W.Ch. (2011) Bioethanol production from alkali-pretreated rice straw by simultaneous saccharification and fermentation. J. Biobased Materials Bioenergy, 5, 396-402.

Manjunath, S.G. and Geeta, G.S. (2007) Effectiveness of fungal pretreatment of agro residues on bioethanol production by yeasts and Zymomonas mobilis. Karnataka J. Agric. Sci. 20, 301-304.

Maruthai, K., Thangavelu, V. and Kanagasabai, M. (2012) Statistical screening of medium components on ethanol production from cashew apple Juice using Saccharomyces diasticus. Int. J. Chem. Biol. Engin. 6, 108-111.

Nuanpeng, S., Laopaiboon, L., Srinophakun, P., Klanrit, P., Jaisil, P. and Laopaiboon, P. (2011) Ethanol production from sweet sorghum juice under very high gravity conditions: Batch, repeated-batch and scale up fermentation. Elect. J. Biotechnol. 14, 20-25.

Egypt. J.Microbiol. 49 (2014) 
Okur, M.T. and Saraçoğlu, N.E. (2006) Ethanol production from sunflower seed hull hydrolysate by Pichia stipitis under uncontrolled $\mathrm{pH}$ conditions in a bioreactor. Turkish J. Eng. Env. Sci. 30, 317-322.

Pavlečić, M., Vrana, I., Vibovec, K., Šantek, M.I., Horvat, P. and Šantek, B. (2010) Ethanol from sugar beet intermediates. Food Technol. Biotechnol. 48, 362-367.

Purwadi, R., Brandberg, T. and Taherzadeh, M.J. (2007) A possible industrial solution to ferment lignocellulosic hydrolysate to ethanol: continuous cultivation with flocculating yeast. Int. J. Mol. Sci. 8, 920-932.

Rajoka, M.I., Ferhan, M. and Khalid, A.M. (2005) Kinetics and thermodynamics of ethanol production by a thermotolerant mutant of Saccharomyces cerevisiae in a microprocessor-controlled bioreactor. Lett. Appl. Microbiol. 40, 316-321.

Saha, B.C. and Cotta, M.A. (2011) Continuous ethanol production from wheat straw hydrolysate by recombinant ethanologenic Escherichia coli strain FBR5. Appl. Microbiol. Biotechnol. 90, 477-487.

Saha, B.C. and Cotta, M.A. (2005) Alkaline peroxide pretreatment, enzymatic saccharification and fermentation of wheat straw to ethanol. In: Proceedings of the $34^{\text {th }}$ Meeting of the United States-Japan Cooperative Program in Natural Resources (UJNR) Food and Agriculture Panel, October $23^{r d}-29^{\text {th }}$, Susoni, Shizuoka, Japan, pp. $168-172$.

Shrestha, P., Khanal, S.K., Pometto, A.L. and van Leeuwen, J. Hans (2009) Ethanol production via in situ fungal saccharification and fermentation of mild alkali and steam pretreated corn fiber. Bioresour. Technol. 101, 8698-8705.

Silva, J.P., Carneiro, L.M. and Roberto, I.C. (2013) Treatment of rice straw hemicellulosic hydrolysates with advanced oxidative processes: a new and promising detoxification method to improve the bioconversion process. Biotechnol. Biofuels , 6, 23-26.

Souza, C.S., Oliveira, K.F., Capela, M.V., Tognolli, J.O. and Laluce, C. (2007a) Optimization of ethanol production by yeast strain 63M and a strategy to improve cell survival at high temperatures. Bioquímica $e$ Biotecnol. http://www.abq.org.br/cbq/2007/trabalhos/11/11-201-123.htm.

Souza, C.S., Oliveira, K.F., Trevisan, H.C. and Laluce, C. (2007b) A strategy to compare yeast strains and improve cell survival in ethanol production processes above $30^{\circ}$ C. Communic Curr. Res. Educ. Topics Trends Appl. Microbiol. 410-417. http://www.formatex.org/microbio/pdf/Pages410-417.pdf.

Talebnia, F. and Taherzadeh, M.J. (2006) In situ detoxification and continuous cultivation of dilute-acid hydrolysate to ethanol by encapsulated Saccharomyces cerevisiae. J. Biotechnol. 125, 377-384.

Taniguchi, M., Suzuki, H., Watanabe, D., Sakai, K., Hoshino, K. and Tanaka, T. (2005) Evaluation of pretreatment with Pleurotus ostreatus for enzymatic hydrolysis of rice straw. J. Biosci. Bioeng. 100, 637-643.

Taniguchi, M., Tanaka, M., Matsuno, R. and Kamikubo, T. (1982) Evaluation of chemical pretreatment for enzymatic solubilization of rice straw. Eur. J. Appl. Microbial. Biotechnol. 14, 35-39. 
Wan, C. and Li, Y. (2010) Microbial pretreatment of corn stover with Ceriporiopsis subvermispora for enzymatic hydrolysis and bioethanol production. Bioresour. Technol. 101, 6398-6403.

Zhang, X., Xu, C. and Wang, H. (2007) Pretreatment of bamboo residues with Coriolus versicolor for enzymatic hydrolysis. J. Biosci. Bioeng. 104, 149-151.

\section{انتاج الأيثانول الحيوى من بعض المخلفات الزراعية و الصناعية

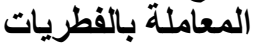

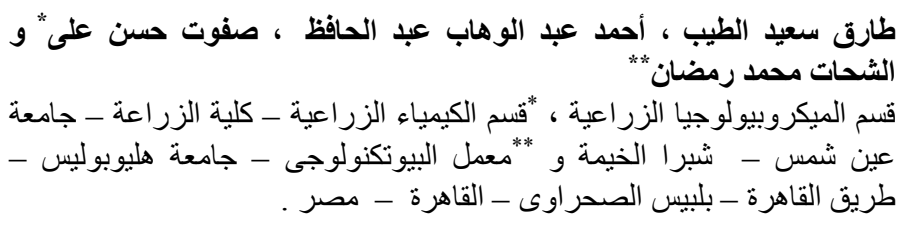

يعتبر انتاج الأيثانول الحيوي من المخلفات اللجنوسيليلوزية احد الاستراتيجيات

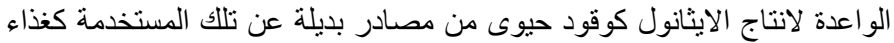

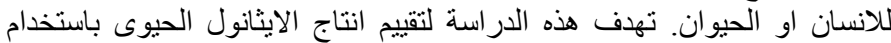

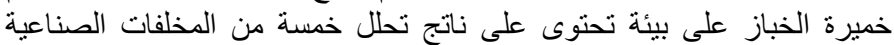

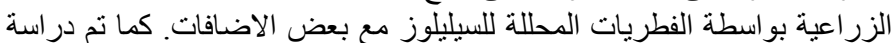

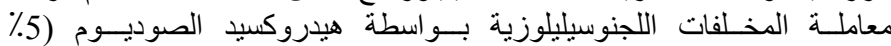

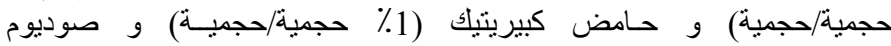
هيبوكلوريت : فوق اكسيد الهيدروجين 1:10 قبل المبيد المعاملة الفطرية. لأنتاج

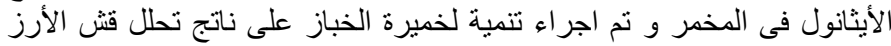

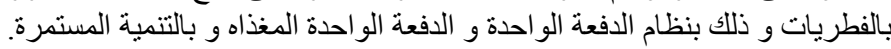

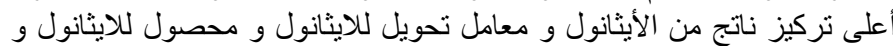

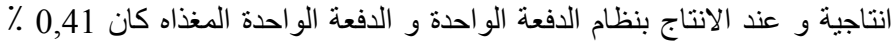

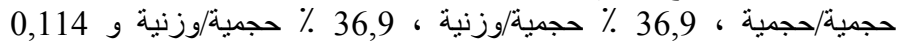

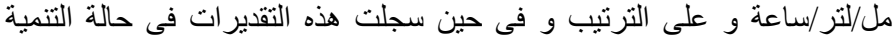

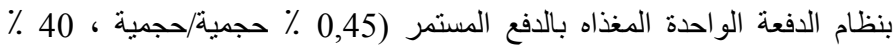

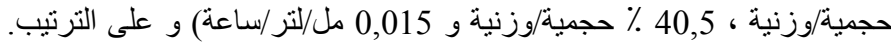

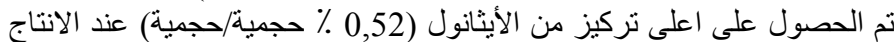

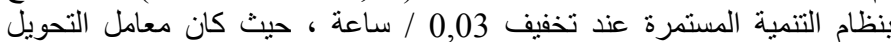

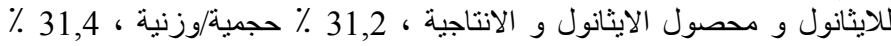
حجمية/وزنية و 0,022 مل/لتر/ساعة , على الترتيب.

Egypt. J.Microbiol. 49 (2014) 